\title{
THE PASSAGE FROM MITH TO ANTI-MYTHIN CONTEMPORARY HISPANIC POETRY
}

\author{
Robert Di Antônio \\ (St Louis)
}

Early in this century's literature there appeared the utilization of already existing myths in a modern context as exemplified by Joyce's Ulysses. Based upon the works of Freud and Jung the arts of the 20's and 30's attempted to return to a sense of primitivism in an effort to recapture those magical and cohesive truths that were lacking in an overly mechanized world.

During those years there were various attempts to artistically produce a primitive form of expression. One need only consider the works of Klee, Picasso, Chagall and the Afro-Cuban school of poets to understand a creative process that has been referred to by some as an escape from our rational scientific world. D. H. Lawrence advocated a return to an earlier life style based upon the recognition of man's blood nature.

The most salient contribution of the pre-World War II Hispanic poetry of García Lorca, Octavio Paz, and Pablo Neruda is the fact that each man deals with the universal philosophical themes of modern man in an original, "nativista" and mythical manner. That is to say, each poet fused his local ambiences and mythologies. They held the belief that a poetry can only be universal by first being specific. Hence these poets linked native traditions, mythologies and cultural elements with the more cosmopolitan aesthetics of universal thought and literature. For example, Octavio Paz fuses Nahuatl and Hindu mythology with the existential problem of man while Neruda universalizes the Chilean landscape and seascape. In Canto general Neruda even fabricates a personal mythology, a new cosmogeny in which man is born from telluric elements of the American soil.

García Lorca's art is deeply rooted in this neo-primitivism of his time. His poetic world recreates those supposed qualities of the

Língua e Literatura, (14), 1985. 
primitive mythic mind that have been so greatly admired by modern poets; that is, its keen awareness of its surroundings and its feeling of co-participation in its universe. To the primitive man his universe was alive with sensory phenomena. Lorca held that primitive man possessed a heightened sense of imagination and it is precisely this vivid imagination that becomes the central consciousness of his poetics. Lorca portrayed primal emotions in his poetic world, emotions which express an atemporal sentiment common to all men in all cultures. Thusly myth is the unifying factor in Lorca's poetics. It is used positively to explain and interpret man's relationship to his surrounding universe. As Howard T Young states, "Lorca was able to raise the gypsies to the level of poetry by, as he put it, inventing a mythology for them. Unlike the sophisticated Greek and Roman myths, the tradition spun by Lorca's fancy remained close to primitive roots." (1) Within Lorca's poetic world he was able to rekindle the primitive link between man and his cosmos. Lorca's personal mythology within the Gypsy Ballads presents a unified attitude toward life, death, and his surrounding universe. However, as Young states concerning Lorca's last book of poetry, Poeta en Nueva York, "The magic, delicate, primitive house of his poetry came tumbling down. In New York this sense of order crumbles, and chaos prevails. Mythical figures are systematically assassinated by negative symbols." (2)

This disintegration of belief reflects Rollo May's feelings. "The old values - the myths and institutions with which civilization consoles itself and explains the unexplainable - are everywhere under attack crumbling." (3)

Jose Hierro graphically portrays the destruction of the myth of the hero, namely it is the anti-myth to Campbell's belief that "In societies where mythology is alive and its archetypal images are understood, the hero undergoes symbolically the trials of life, death, transfiguration, and rebirth and relates them to his society as well as to the cosmos." (4) Hierro presents the hero of the failed quest. The mythological cycle is presented as broken, as incomplete. His hero is a selfless everyman. Hierro's "Requiem" reflects Irving Howes" observation that) "The modern hero moves from the heroic deed to the heroism of consciousness, a heroism often available only in defeat. He comes as a conqueror and stays as a

(1) - Howard T. Young, The Victorious Expression (Madison, Wisconsin: University of Wisconsin Press, 1966), p. 165.

(2) - Ibid., p. 181'

(3) - "Yes Begins with a No," Time, June 22, 1970, p. 66.

(4) - "The Need for New Myths," Time, jan. 17, 1972., p. 50. 
pilgrim." (5) He learns the words of Kyo Gisors in Malraux's Man's Fate that "a man resembles his suffering." (6) Hierro's antimythic vision presents the tragedy of the modern anti-hero on a journey that has only a pale semblance to the heroic aspirations of the past. If the traditional hero embodied the will and hope of his people and if he were to be the embodiment of their highest ideals and striving, then Hierro's modern day everyman is the anti-hero, unsure of himself, hardly a cut above the ordinary. His is not a total struggle to break the bonds of human limitations but it is merely an attempt to survive. Everywhere Hierro stresses the non-heroic nature of the present. His work is a poetic "Requiem" for our mythless age. It is the mimetic poet's role to bring this sad fact to the audience. He is asking them to go beyond the work to gain from his writings a heightened sense of loyalty to a humanistic ethic. $\mathrm{He}$ asks the reader to be committed to man, to all men, since the antihero's suffering and meaningless existence is our own. Hierro is

But a temporary analgesic for existential pain does axit. Love, contemporary [writers] say with Matthew Arnold, while it connot eradicate the slings and arrows of an outrageously ravaged universe, offers some consolation those who suffer them. The essence of existence is unquestionably 'nada,' but some solace is discoverable in the clean well-lighted places of the human heart. In this respect, these novelists appear unwilling or unable to remain completegly true to the vision that life is meaningless. Or at least they do not insist that despair represents the only possible human response to life's absurdity.

not decrying man's fate. He is seeking compassion for as he says, "Estaba al punto de llorar." (8) This view is echoed by Rollo May who believes that love and human contact "can defeat if only for the moment. the utterly unb earable situation of anonymity" (9) For Hierro the past myth, the ancient heroic traditions haunt man diminishing his stature. They stand at every turn mocking him. "The fundamental conflict fought out in the. literature. of our age is not between man and society but between nihilism and the

p. 36 .

(5) - Irving Howe, Literary Modernism (New York: Fawcett, 1967)

(6) - Ibid., p. 36 .

(7) - Charles B. Harris, Contemporary American Novelists of the Absurd (New Haven, Conn.: College and University Press, 1971), p. 31 .

(8) - José Hierro, Obras completas 1944-1962 (Madrid: Ediciones Griner, 1962), p. 459.

(9) - "Yes Begins with a No," Time June 22, 1970, p. 66 
nostalgia for the absolute. "(10) Hierro's attitude toward man could be called concerned compassion. He mas employed anti-myth to graphically point to this fact. The myth of the hero is shattered in Hierro's poem "Requiem." The past myths are decried as illusionary and repressive to modern man. Hierro has not sought to engrandize man but confides in his reading public sharing his pain with them. It will be the reader's role to act to make bearable this non-heroic present, this age of ananymity. If Campbell's belief is correct that myth "is a rather valid explanation of the truth. offering. . man a comprehensive, understandable image of the world around him," (11) them by extension the poets of anti-myth point to a negative myth, a myth which states that ours is a universe bereft of truth and logicality.

Whereas Hierro has chosen to confront the anti-mythic present with a plea for compassion and understanding, Nicanor Parra has carried this absurdist vision of reality one step further He has begun by shattering man's islands of hope. The myths of civilization and progress are damned by the poet. "El Occidente es un gran pirámide/Que termina y empieza en une psyquiatra/la pirámide está por derrumbar-se." (12) It is Rollo may whose famous maxim begins "Yes begins with a No," (13) who mirrors the thinking of the writers of anti-literature in their attempt to face up the myth of the absurd and utilize it as a point of departure. Again Irving Howe's observations are relevant. "The modern hero discovers that he cannot be a hero. Yet only through his readiness to face the consequences of this discovery can he salvage a portion of the heroic" (14) Parra is not attempting to console man or reform the world for he is far beyond this point. He has no facile solutions for the absurdity of existence. His poetics are aimed at a means of facing life and creating a world view that will make existence bearable. "The writer, in picturing the absurdity of the human condition, is in effect protesting against it. Life must be lived, even though the search for ultimate meaning is foiled." (15)

Parra's work expresses what Wylie Sypher refers to as postexistentialist humanism. Sypher observes, "As long as man is aware

(10) - Charles I. Glickberg, The Self in Modern Literature (University Park, Penn.: The Pennsylvania State University Press, 1969), p. 185.

(11) - "The Need for New Myths," Time, Jan. 17, 1972, p. 50.

(12) - Nicanor Parra, Obra gruesa (Santiago de Chile: Editorial Universitaria, 1969), p. 163 .

(13) - "Yes Begins with a No," Time, Jan. 22, 1970, p. 66.

(14) - Howe, p. 36.

(15) - Charles I. Glicksberg, Ironic Vision in Modern Literature (The Hague: Martinue Nijhoff, 1969), p. 223. 
of the void at the center of thing. and the absurdity of his position in it, there is some locus for a sort of humanism, even if it be unlike any kind of humanism held in the past." (16) He goes on to explain that contemporary writers "find it impossible to escape from the consciousness of their own negligibility and of the nonsensicality of their world. Man cannot alienate himself from his own consciousness." (17) Sypher also postulates that "It is too soon to tell whether a-literature, anti-literature, anti-theater, anti-painting, and so-to-speak anti-science can really afford us foundations for a new humanism." (18) However, in the case of Parra's work one finds that this newly defined humanism certainly permeates his poetry for his crippled heroes are ennobled as they defy the absurd in the only way possible them. through cynicism, humor and irony His antipoetic vision foreshadowed that of today's absurdist writers.

The absurdity of the muman condition, if faced squarely, can be viewed as a cosmic joke. Thus, while the novelist of the absurd emphasizes the blackness of modern existence, the response he seeks is neither stoic resignation for Camusian scorn, but laughter. In this aim he is at one with French dramatists of the absurd, who believe that the dignity of man lies in his ability to face reality in all its senselessness; to accept it freely, without fear, without illusions - and to laugh at it. (19)

In essence José Hierro and Nicanor Parra essentially share the same philosophical outlook regarding man and his place in the universe. However, Hierro like the existentialist writers presents his vision of man's tragic plight in a logical and intellectual manner while Parra, like the absurdist writers, expresses the senselessness of the human condition in a non rational and sometimes comic fashion. "In much modernist literature, one finds a bitter impatience with the whole apparatus of cognition and the limiting assumption of rationality. a major impulse in modernist literature is a choking nausea before the idea of culture, there is another in which the writer takes upon himself the enormous ambition not to remake the world (by now seen as hopelessly recalcitrant and alien) but to reinvent the terms of reality." (20)

Anti-mythic poetry has had a great influence on the Hispanic poetry of the last two decades. At one time or another in their de-

(16) - Wylie Sypher, Loss of the Self in Modern Literature (New York: Vintage, 1964), p. 7.

(17) - Ibid., p. 7.

(19) - Harris, p. 30. p. 16 .

(20) - Irving Howe, Literary Modernism (New York: Fawcett, 1967), 
velopment the following Chilean writers have passed through an anti-mythic and anti-poetic phase: Enrique Lihn, Raul Rivera, Gabriel Carvajal, Mario Ferrero, Armando Uribe, and even Peblo Neruda in his work Estravagario. The Argentine poet Simon Kargieman wrote a book called Antipoems 1962 modeled after Parra's poetry. Another Argentine, Juan Gelman, has a work called Traduciones III: Los poems de Sidney West which is a new and innovative direction based on an anti-poetic conceit. Other South American writers who have utilized anti-myth and the anti-poem are Mario Benedetti of Uruguay, Carlos Rebolledo of Venezuela, Aristides Martinez of Parama, Oscar Ichaza of Bolivia, Ernesto Cardenal of Nicaragua, and a host of lesser poets. However, it must be stated that Parra stands as the undisputed master of anti-poetry in the Hispanic world.

The role of the anti-poet and the negativist writers of antimythic literature if deeply analyzed reveals an underlying sense of commitment to man. Their purpose is not merely to tear down existing order nor solely to destroy the myths of our time. Their overt pose is that of an iconoclast but beneath their ironic vision is a sense of quest.

Even the most confirmed upholder of the myth of the absurd is impelled by a "religious" need.. The new Adam, a technological Prometheus in a de-Christianized culture, lives in the flux of time and strives, however, blindly, to establish the Kingdom of Heaven on earth for he is convinced it can be established nowhere else. But this vision of a utopian consummation sometime in the future has been shattered. The quest for an absolute goes on. If reason seeks the light of truth in Nature, the heart crave the certitudes borne of faith. This is the torment of 20th century man in a predominantly secular and skeptical age as he tries to believe in God. The religious motif, however paradoxical its expression, persists in the nihilistic literature of our time. (21).

Although writers like Nicanor Parra and José Hierro seemingly damn the myths of our time in their anti-works, their ironic guise or posture evolves as a protective device. They endow man with irony. Irony is a salvific force in their poetics. "Irony saves him [man] from losing his grip and enables him to return some measure of sanity."(22) Furthermore, if these contemporary Hispanic pots felt existence to be truly absurd and meaningless then art would be merely a vain projection of consciousness and any attempt at

(21) - Glicksberg, p. 259.

(22) - Glicksberg, p. 12. 
personal communication or creation would be a fruitless myth in and of itself. "Hence, to maintain that life is a nightmare of absurdity and to do so within the controlled framework of art, is paradoxically a way of triumphing over it." (23) The mere act of creation then becomes a positive gesture, one which affirms a faith in art as a salvific and positive force. The act of writing becomes affirmative in that the writer, while aware of the human predicament, whether he decries it like Hierro or laughs at it like Parra, is in a sense revolting against the myth of the absurd. His work of art is in and of itself a revolt; it is his quest to comprehend man's relationship to his universe. This attempt at comprehension, be it ironic, satiric, or lamentful, ultimately evolves into an ennobling attempt to know the meaning of existence.

The essence of this work can best be summed up and exemplified by two quotes from Monroe K. Spears. Both of the subsequent quotes will graphically portray the philosophical rationale behind the movement from the poetics of myth to today's emphasis of the poetics of anti-myth.

In the first quote Spears writes of " myth as a means of bridging discontinuities and of achieving a deeper level and a community of consciousness." (24)

Spears then goes on to contrast the poetry of myth to the poetry of anti-myth stressing in particular the function of the antipoem.

In the revolution of the 1950's this emphasis was reversed, and there was a drive away from rhetorical discontinuity and back toward statement, toward poetry conceived of as not something uttered by a "persona" or a fragment of a drama but as direct confession or revelation or prophecy by the poet undisguised. The attempt, sometimes very artful, is to produce an impression of artlessness, and to involve the reader. The drive is toward openness, toward eliminating any aesthetic discontinuity; the poem is no longer timeless artifact, but designed to draw the reader into time, immerse him in immediate experience. (25)

(23) - Glicksberg, p. 13 .

(24) - Monroe K. Spears, Dionysius and the City (New York: Oxford, 1970), p. 265 .

(25) - Ibild., p. 265. 